\title{
Urinary amino-acetone excretion in lead workers
}

\author{
H. A. WALDRON
}

From the Medical Department, Vauxhall Motors Ltd., Luton

SYNOPSIS Urinary amino-acetone concentrations were determined in a group of 51 persons with industrial exposure to lead and the findings compared with those obtained from a control group of 27 persons having no exposure to lead.

A good correlation was found between delta-aminolaevulinic acid and amino-acetone excretion in the control group but this correlation was not so well defined in the lead-exposed group. In this group excretion of amino-acetone seemed to be better correlated with excretion of delta-aminolaevulinic acid for values less than $0.6 \mathrm{mg} . \%$ than with values greater than $0.6 \mathrm{mg} . \%$. All the men concerned in the investigation were employed in dusty occupations. Hypotheses are put forward to attempt to explain the differences in excretion of amino-acetone noted amongst lead workers with high excretion of delta aminolaevulinic acid.

Little correlation was found between amino-acetone excretion and that of either porphobilinogen or coproporphyrin.

Amino-acetone is formed by the condensation of glycine with acetyl coenzyme-A (Gibson, Laver, and Neuberger, 1958; Kikuchi, Kumar, and Shemin, 1959; Urata and Granick, 1961) or by the oxidation of the hydroxyl group of L-threonine (Elliott, 1959; Neuberger and Tait, 1960; Urata and Granick, 1961). Its role in metabolism may be as part of a cycle by which glycine and threonine can be oxidized, and such a cycle was postulated by Elliott (1959) as an alternative (Fig. 1) to the succinate-glycine cycle of Shemin, Russell, and Abramsky (1955).

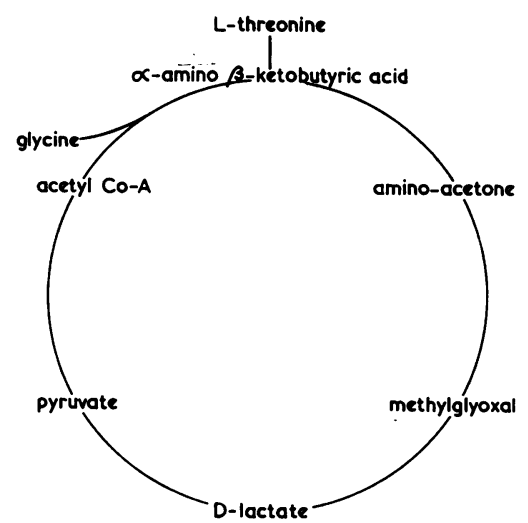

FIG. 1. The amino-acetone-acetate cycle.
Amino-acetone was first reported to be present in the urine of normal individuals by Mauzerall and Granick (1956) and subsequently was found to be absent from the urine of animals with experimental porphyria (de Matteis, 1962) and of patients with acute intermittent porphyria (de Matteis and Rimington, 1962). An hypothesis was put forward by these authors to explain the metabolic defect in acute intermittent porphyria on the basis of preferential metabolism of glycine through the succinatedelta-aminolaevulinic acid cycle rather than through the acetate-amino-acetone cycle (Fig. 2). It is well known that the symptoms of lead poisoning and those of acute intermittent porphyria are very similar, so much so that it has been suggested that the mechanism of the production of the symptoms

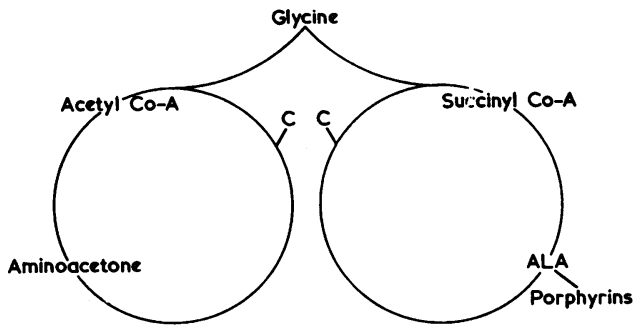

FIG. 2. Glycine-delta-aminolaevulinic acid and aminoacetate cycles. $C=$ alpha carbon atoms of glycine to purines, formate, etc. 
of the two diseases might have a common metabolic pathway (Goldberg, Smith, Lockhead, and Dagg, 1962). Although recent reports in which aminoacetone was found in the urine of animals with experimental porphyria (Granick and Urata, 1963) and of patients with acute intermittent porphyria (Tschudy, Welland, Collins, and Hunter, 1963) have cast some doubts on the hypothesis of de Matteis and Rimington, it was thought worthwhile to conduct a survey amongst workers exposed to lead to see whether any differences in their excretion of amino-acetone were noted as compared with that of a normal control group.

\section{METHOD}

Urinary concentrations of amino-acetone were measured in a group of 51 workers with exposure to lead and, as a control, in a group of 27 persons with no history of exposure to lead. In addition delta-aminolaevulinic acid and porphobilinogen were determined on each urine specimen, which, as was amino-acetone, were estimated by a modification of the method of Urata and Granick (1963) as follows.

\section{REAGENTS}

RESINS All the resins were stored wet before use.

Dowex $2 \times 8,200-400$ mesh Small particles were removed from the resin and the resin was converted to the acetate form by washing first with $3 \mathrm{M}$ sodium acetate until the eluate was chloride-free and then with water until the eluate was neutral to litmus.

Dowex $50 \times 8,200-400$ mesh After removal of small particles the resin was converted to the sodium form by allowing it to stand overnight with $2 \mathrm{~N}$ sodium hydroxide. It was then washed until neutral and reconverted to the acid form by washing with 1 vol. $4 \mathrm{~N} \mathrm{HCl} .6$ vol. $2 \mathrm{~N}$ $\mathrm{HCl}, 6$ vol. $1 \mathrm{~N} \mathrm{HCl}$, and 6 vol. water.

Amberlite IRC 50, 100-200 mesh The resin was washed in succession with 10 vol. $1 \mathrm{~N} \mathrm{NaOH}$, water, 10 vol. $1 \mathrm{~N} \mathrm{HCl}$, water, 10 vol. acetate buffer $(p \mathrm{H} \mathrm{4.6)}$, and water.

\section{ACETIC ACID $1 \mathrm{M}$ and $0.2 \mathrm{M}$.}

SODIUM ACETATE $\quad 0.5 \mathrm{M}$ and $3 \mathrm{M}$.

ACETATE BUIFER ( $p$ H 4.6) Glacial acetic acid, $57 \mathrm{ml}$, and $136 \mathrm{~g}$. of sodium acetate trihydrate were made up to 1 litre with water.

HYDROCHLORIC ACID, 2 N

\section{ACETYLACETONE}

MODIFIED EHRLICH REAGENT p-Dimethylaminobenzaldehyde, $1 \mathrm{~g}$., was dissolved in $20 \mathrm{ml}$. of glacial acetic acid and $8 \mathrm{ml}$. of $72 \%$ perchloric acid added. The solution was diluted to $50 \mathrm{ml}$. with acetic acid. The reagent was prepared freshly each time.

\section{PROCEDURE}

Urine, $1 \mathrm{ml}$., was introduced onto a column of the prepared Dowex 2 resin $2 \times 1 \mathrm{~cm}$. The urine flowed through into a test tube, A, and the column was washed with $4 \mathrm{ml}$. of water, also collected in tube A. Porphobilinogen was eluted from the resin with $2 \mathrm{ml}$. of $1 \mathrm{M}$ acetic acid and $2 \mathrm{ml}$. of $0.2 \mathrm{M}$ acetic acid. The combined eluates were diluted to $10 \mathrm{ml}$. with water and equal volumes of this solution and the Ehrlich reagent were allowed to react together for exactly 15 minutes. The optical density of the solution was then measured in the spectrophotometer at $553 \mathrm{~m} \mu$ against a reagent blank in cells of $1 \mathrm{~cm}$. optical path. The concentration of porphobilinogen was read off from a calibration graph prepared from porphobilinogen isolated from the urine of a patient with acute intermittent porphyria by the method of Cookson and Rimington (1954).

The contents of tube A were passed through a column of Amberlite resin $(1 \times 7 \mathrm{~cm}$.) to adsorb the aminoacetone. The eluate was collected in a separate tube, $B$. The Amberlite column was washed with $10 \mathrm{ml}$. of water which was also collected into tube B. Amino-acetone was eluted from the column with $9 \mathrm{ml}$. of $2 \mathrm{~N} \mathrm{HCl}$ and neutralized to $p \mathrm{H} 4.6$ with $5 \mathrm{ml}$. $3 \mathrm{M}$ sodium acetate. The volume of the solution was made up to $15 \mathrm{ml}$. with water and $2 \mathrm{ml}$. was incubated with $0 \cdot 1 \mathrm{ml}$. acetylacetone for 10 minutes at $100^{\circ} \mathrm{C}$. to convert the amino-acetone to 2,4-dimethyl-3-acetylpyrrole which gives a red coloured compound with the Ehrlich reagent. After cooling, equal volumes of the solution and the Ehrlich reagent were mixed and the optical density of the solution determined after exactly 15 minutes at $556 \mathrm{~m} \mu$. Concentrations of amino-acetone were read off from a graph prepared from amino-acetone toluene-p-sulphonate ${ }^{1}$.

The eluate in tube $\mathbf{B}$ was passed through a column of Dowex $50(1 \times 2 \mathrm{~cm}$.) and the column was washed with $16 \mathrm{ml}$. of water to free the column of urea. The column was washed with $3 \mathrm{ml} .0 .5 \mathrm{M}$ sodium acetate and deltaaminolaevulinic acid eluted with $7 \mathrm{ml}$. $0.5 \mathrm{M}$ sodium acetate. Acetyl-acetone, $0.25 \mathrm{ml}$., was added to the eluate and the volume made up to $10 \mathrm{ml}$. with acetate buffer $(p \mathrm{H} \mathrm{4}$.6). The solution was incubated for 10 minutes at $100^{\circ} \mathrm{C}$. to convert the delta-aminolaevulinic acid to 2-methyl-3-acetyl-4-propionic acid pyrrole. After cooling, $2 \mathrm{ml}$., of the solution was mixed with an equal volume of Ehrlich reagent and the optical density of the solution determined at $553 \mathrm{~m} \mu$ after exactly 15 minutes. Concentrations of delta-aminolaevulinic acid were read off from a calibration chart prepared from commercially obtained delta-aminolaevulinic acid $\cdot \mathbf{H C l}$ (L. Light \& Co.).

The pyrroles formed by the reaction with acetylacetone were identified by the chromatographic method of Urata and Granick (1963).

Urinary coproporphyrin concentrations were determined using a slight modification of the chromatographic method of Schlenker, Davis, and Kitchell (1963).

${ }^{1}$ This material was obtained from Professor C. Rimington to whom I am most grateful. 
RESULTS

The mean concentration of urinary amino-acetone in the control group was found to be $0.22 \mathrm{mg} . \%$ (range $0 \cdot 15-0 \cdot 31 \mathrm{mg} . \%$ ). The mean delta-aminolaevulinic acid concentration in this group was $0.28 \mathrm{mg}$. \% (range, $0.06-0.51 \mathrm{mg}$. \%). There was a good correlation between concentrations of aminoacetone and delta-laevulinic acid as shown in Figure 3. The first results from the test group indicated that there was some correlation between their excretions with values for delta-aminolaevulinic acid up to about $0.6 \mathrm{mg}$. $\%$ but above this value it seemed that the values of amino-acetone became

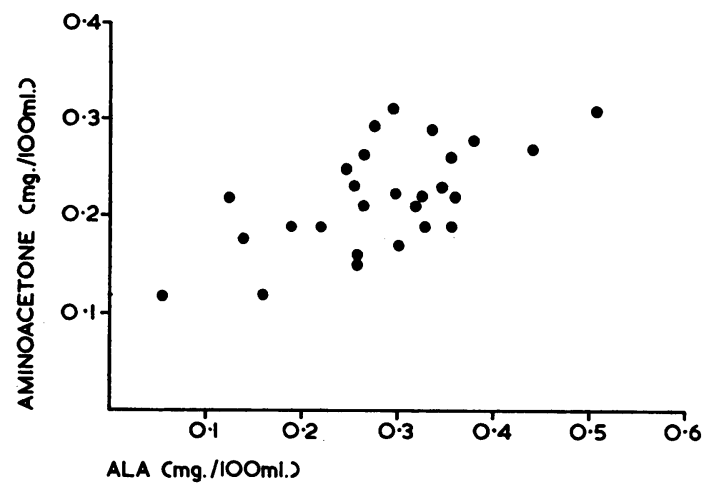

FIG. 3. Correlation between delta-aminolaevulinic acid and amino-acetate excretion in control group.

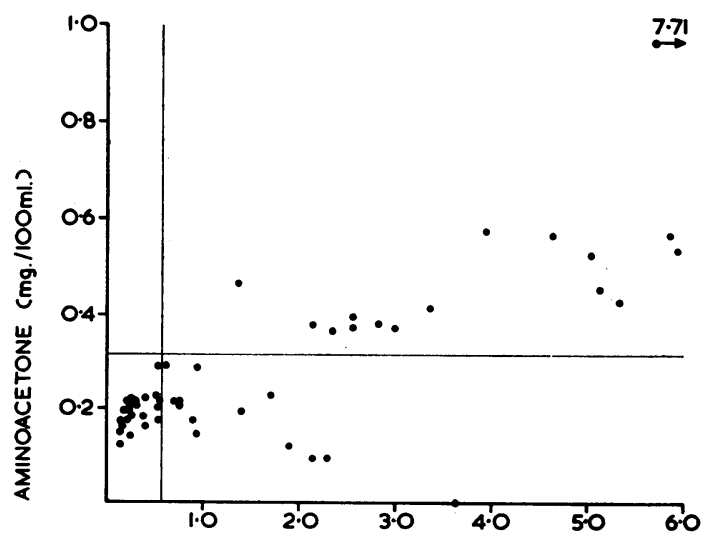

ALA (mg./100ml.)

FIG. 4. Correlation between delta-aminolaevulinic acid and amino-acetone excretion in lead-exposed group. Line parallel to abscissa = normal upper limit of amino-acetone excretion. Line parallel to ordinate $=$ normal upper limit of delta-aminolaevulinic acid excretion. much more widely scattered. To test this impression further, urine was obtained from a number of workers who were known to be excreting large amounts of delta-aminolaevulinic acid. Results obtained from these workers showed that although there was a tendency for amino-acetone values to rise simultaneously with delta-aminolaevulinic acid, occasionally values for amino-acetone were obtained which were lower than might have been expected (Fig. 4.)

The results of the determinations of aminoacetone for the lead-exposed group are given in Table I. Figures are shown for the whole group and

\section{TABLE I}

URINARY AMINO-ACETONE EXCRETION IN THE LEAD-EXPOSED WORKERS

\begin{tabular}{lllc} 
& $\begin{array}{l}\text { Whole } \\
\text { Group (51) }\end{array}$ & $\begin{array}{l}\text { Workers with Delta- } \\
\text { aminolaevulinic Acid } \\
<0.6 \mathrm{mg} \% \%(22)\end{array}$ & $\begin{array}{c}\text { Workers with Delta- } \\
\text { aminolaevulinic Acid } \\
>0.6 \mathrm{mg} . \%(29)\end{array}$ \\
\hline Mean & 0.30 & 0.21 & $\begin{array}{c}0.37 \\
\text { Range }\end{array}$ \\
$0-0.97$ & $0.15-0.30$ & Nil-0.97
\end{tabular}

also for workers with delta-aminolaevulinic acid concentrations greater than $0.6 \mathrm{mg} . \%$ and less than $0.6 \mathrm{mg} . \%$. It will be seen from Table I that although the mean amino-acetone values for the workers with a level of delta-aminolaevulinic acid $>0.6 \mathrm{mg} . \%$ was higher than that of the control group, the value obtained from the workers with a level $<0.6 \mathrm{mg} . \%$ was almost identical with that of the control group. Coproporphyrin values in the lead-exposed group were higher than in the control group, as one would expect. There was some tendency for aminoacetone values to rise with increasing coproporphyrin levels, but at the higher values of coproporphyrin the scatter of those values was very wide (Fig. 5). The mean coproporphyrin concentration found in the control group was $31 \mu \mathrm{g}$./l. (range 5-80 $\mu \mathrm{g}$./l.).

Little difference was observed between the mean porphrobilinogen values found in the two groups. The mean result for the control group was $0.6 \mathrm{mg} . \%$ (range, 0-0.12 mg. \%); for the test group the mean was $0.08 \mathrm{mg} . \%$ (range, $0-0.36 \mathrm{mg} . \%$ ). In three workers the level was greater than $0.2 \mathrm{mg} . \%$. In one man with a porphrobilinogen level of $0.22 \mathrm{mg} . \%$ the amino-acetone level was $0.54 \mathrm{mg} \%$ and deltaaminolaevulinic acid $5.96 \mathrm{mg} . \%$, and in the two other cases, the porphrobilinogen values were $\mathbf{0 . 2 8}$ and $0.36 \mathrm{mg} . \%$ associated with amino-acetone values of 0.97 and $0.82 \mathrm{mg} . \%$ and delta-aminolaevulinic acid values of 7.71 and $5.19 \mathrm{mg} . \%$ respectively. Generally no correlation between porphobilinogen and amino-acetone was found. 


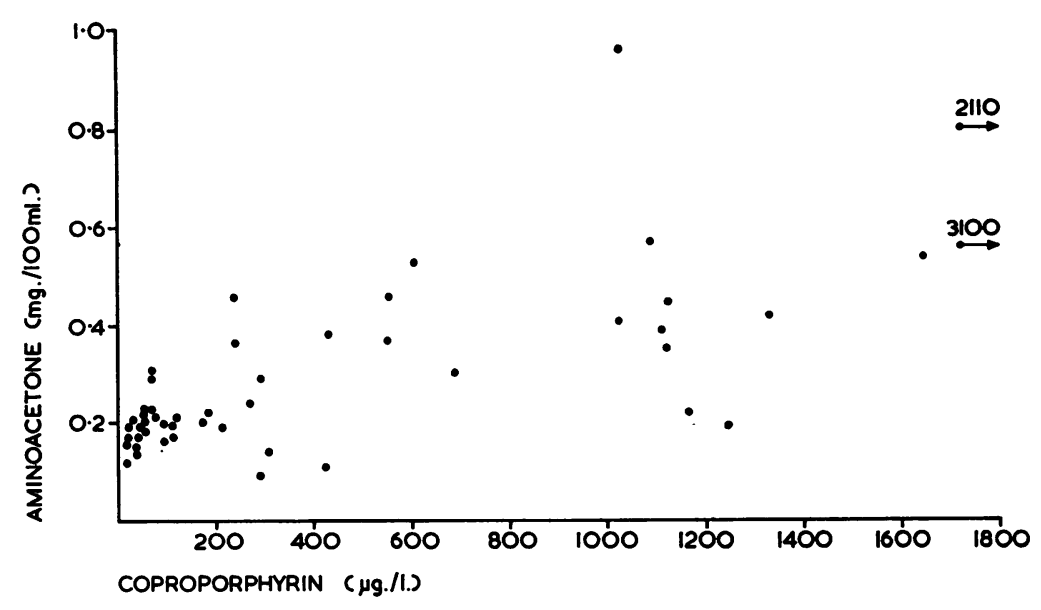

FIG. 5. Correlation between amino-acetone and coproporphyrin in lead-exposed group.

\section{DISCUSSION}

The correlation between amino-acetone and deltaaminolaevulinic acid excretion was not so well defined in the lead workers as in the control group. In the lead workers, the correlation was rather better for delta-aminolaevulinic acid values less than $0.6 \mathrm{mg} . \%$ than for the values above this figure (the upper limit of normal quoted by HaegerAronsen, 1960). Above the level of $0.6 \mathrm{mg} . \%$ the excretion of amino-acetone becomes very erratic.

Of the workers with an excretion of delta-aminolaevulinic acid $>0.6 \mathrm{mg} . \%, 16 \mathrm{had}$ a concentration of amino-acetone above $0.31 \mathrm{mg} . \%$, the upper limit of normal found, whereas the remaining 13 workers had values of 0.31 or less. In one worker with an excretion of delta-aminolaevulinic acid of $3.63 \mathrm{mg} . \%$ no amino-acetone was found at all. The mean value of amino-acetone for those workers with a level of $>0.6 \mathrm{mg} . \%$ of delta-aminolaevulinic acid, however, was noticeably higher than that of the control group and the very highest values were all accompanied by high excretion of amino-acetone.

None of the workers examined was suffering from frank clinical plumbism, but in one case of lead poisoning examined by Schlenker (1964) the level of amino-acetone was found to be slightly decreased and those of delta-aminolaevulinic acid and porphobilinogen were elevated. The finding of raised amino-acetone levels amongst some of the lead workers was unexpected in the light of enzymatic studies performed in animals by Tschudy (1964) who was of the opinion, as a result of this work, that lead would be unlikely to increase excretion of amino-acetone.

The explanation to account for the differences in excretion of amino-acetone among the workers with evidence of lead absorption is at present obscure although two theories might be put forward. It may be that in some cases glycine is preferentially metabolized through the succinate-delta-aminolaevulinic acid cycle, as postulated by de Matteis and Rimington (1962), and this would account for the low aminoacetone values found. On the other hand, lead may impose a partial blockage in the synthesis of other metabolites in the glycine-amino-acid-delta-aminolaevulinic acid cycles which could result in the high levels of both these amino-acids found. It is known that the carbon atoms bearing the amino-group in both amino-ketones are precursors of $\mathrm{C}^{2}$ and $\mathrm{C}^{8}$ of guanine and uric acid and also of formate (Nemeth, Russell, and Shemin, 1957; Kikuchi, Kumar, and Shemin, 1959), so this theory might be confirmed if concentrations of these substances were found to be diminished in persons with high amino-ketone excretion. A mechanism of this kind has been observed by Talman, Case, Nevé, Labbe, and Aldrich (1955), who found a decrease in purine synthesis which ran parallel with an increase in porphyrin in chick embryos given experimental porphyria with Sedormid. A great deal more work would need to be undertaken, however, before either of these hypotheses could be verified.

I am grateful to Mr. H. Buchwald, Dr. J. M. Muir, and Dr. S. G. Rainsford for supplying me with urine specimens from lead workers with high excretion of deltaaminolaevulinic acid. My thanks are also due to Dr. A. J. de Kretser for advice and encouragement and to Dr. A. R. Thompson and the management of Vauxhall Motors for permission to publish this paper.

\section{REFERENCES}

Cookson, G. H., and Rimington, C. (1954). Biochem. J., 57, 476. de Matteis, F. (1962). Panminerva med., 4, 368. 
de Matteis, F., and Rimington, C. (1962). Lancet, 1, 1332. Elliott, W. H. (1959). Nature (Lond.), 183, 1051.

Gibson, K. D., Laver, W. G., and Neuberger, A. (1958). Biochem. J., 70,71 .

Goldberg, A., Smith, J., Lochhead, A., and Dagg, J. (1962). Scot. med. J., 7, 330.

Granick, S., and Urata, G. (1963). J. biol. Chem., 238, 821.

Haeger-Aronsen, B. (1960). Scand. J. clin. Lab. Invest., 12, suppl. 47.

Kikuchi, G., Kumar, A., and Shemin, D. (1959). Fed. Proc., 18, 259.

Mauzerall, D., and Granick, S. (1956). J. biol. Chem., 219, 435.

Nemeth, A. M., Russell, C. S., and Shemin, D. (1957). Ibid., 229, 415.

Neuberger, A., and Tait, G. H. (1960). Biochim. biophys. Acta (Aust.), 41, 164.
Shemin, D., Russell, C. S., and Abramsky, T. (1955). J. biol. Chem., 215, 613.

Schlenker, F. S. (1964). Personal communication.

-, Davis, C. L., and Kitchell, C. L. (1963). Amer. J. clin. Path., 39, 531.

Talman, E. L., Case, J. D., Nevé, R. A., Labbe, R. F., and Aldrich, R. A. (1955). J. biol. Chem., 212, 663.

Tschudy, D. P. (1964). Personal communication.

, Welland, F. H., Collins, A., and Hunter, G. (1963). Lancet, 2,660 .

Urata, G., and Granick, S. (1961). Biochem. biophys. Res. Commun. $4,96$.

- L (1963). J. biol. Chem., 238, 811.

\section{Broadsheets prepared by the Association of Clinical Pathologists}

The following broadsheets (new series) are published by the Association of Clinical Pathologists. They may be obtained from Dr. R. B. H. Tierney, Pathological Laboratory, Boutport Street, Barnstaple, N. Devon. The prices include postage, but airmail will be charged extra.

3 The Detection of Barbiturates in Blood, Cerebrospinal Fluid, Urine, and Stomach Contents. 1953. L. C. NICKOLLS. 1s.

4 The Estimation of Carbon Monoxide in Blood. 1953. D. A. STANLEY. $1 \mathrm{~s}$.

13 The Identification of Serotypes of Escherichia coli Associated with Infantile Gastro-enteritis. 1956. JOAN TAYLOR. $1 \mathrm{~s}$.

16 Preservation of Pathological Museum Specimens. 1957 L. W. PROGER. 1s.

17 Cultural Diagnosis of Whooping-cough. 1957. B. W. LACEY. $1 \mathrm{~s}$.

20 Investigation of Porphyrin/Porphyria. 1958 (reprinted 1962). C. RIMINGTON. 2s.

23 The Dried Disc Technique for Bacterial Sensitivity Tests. 1959. R. W. FAIRBROTHER and J. C. SHERRIS. $1 \mathrm{~s}$.

24 Safe Handling of Radioactive Tissues in the Laboratory and Post-mortem Room. 1959. R. C. CURRAN. $1 \mathrm{~s}$.

26 The Periodic Acid-Schiff Reaction. 1959. A. G. E. PEARSE. $1 \mathrm{~s}$.

28 Daily Fatty Acid Excretion. 1960. A. C. FRAZER. $2 s$.

29 The Preparation of Bone for Diagnostic Histology. 1960. D. H. COLlins. $2 \mathrm{~s}$.

30 Control of Accuracy in Chemical Pathology. 1961. G. H. GRANT. 4s.

31 Investigation of Haemorrhagic States with Special Reference to Defects of Coagulation of the Blood. 1961. E. K. BLACKBURN. 4s.

32 Detection of Resistance to Streptomycin, P.A.S., and Isoniazid in Tubercle Bacilli. 1961. R. CRUICKSHANK and S. M. STEWART. 2s.

33 The Laboratory Detection of Abnormal Haemoglobins. 1961. H. LeHMANN and J. A. M. AGER. 4s.
34 Titration of Antistreptolysin O. 1961. H. GOODER and R. E. O. WILliams. $2 s$.

35 The Estimation of Faecal 'Urobilinogen'. 1961. C. H. GRAY. 2 s.

36 Quantitative Determination of Porphobilinogen and Porphyrins in Urine and Faeces. 1961. c. RIMINGTON. 3s. 6d.

37 The Paper Electrophoresis of Serum and Urinary Proteins. 1961. G. FRANGLEN and N. H. MARTIN. 4s.

38 The Augmented Histamine Gastric Function Test. 1961. M. LUBRAN. $2 s$.

39 Investigation of Haemolytic Anaemia. 1961. J. G. SELWYN. $2 \mathrm{~s}$.

40 Short-term Preservation of Bacterial Cultures. 1962. E. JOAN STOKES. 2s.

41 Serological Tests for Syphilis. 1962. A. E. WILKINson. 6 s.

42 The Determination of Glucose 6-Phosphate Dehydrogenase in Red Cells. 1962. T. A. J. PRANKERD. 2s.

43 Mycological Techniques. 1962. R. W. RIDDELL. 3s. 6d.

44 The Laboratory Investigation of Catecholamine Secreting Tumours. 1963. M. SANDLER and C. R. J. RUTHVEN. 2s.

45 Diagnostic Test for Hereditary Galactosaemia. 1963. v. SCHWARTZ. $2 s$.

46 The Determination of Serum Iron and Total Iron Binding Capacity. 1963. A. JORDAN and D. A. PODMORE. 2s.

47 Nuclear Sexing. 1964. B. LeNNox and W. M. DAVIDSON. 2s.

48 The Laboratory Investigation and Control of the Defibrination Syndrome. 1964. R. M. HARDISTY, G. I. C. INGRAM, and A. A. SHARP. 3s. 6d. 